\title{
Economic viability of a canadian biodigester for power generation in dairy farming
}

\section{Viabilidade econômica da implantação de um biodigestor tipo canadense para a geração de energia elétrica destinada à atividade leiteira}

\author{
Fabiana Alves Demeu'; Marcos Aurélio Lopes ${ }^{2 *}$; Eduardo Mitke Brandão Reis ${ }^{3 ;}$ \\ André Luis Ribeiro Lima4; Francisval de Melo Carvalho4; Julio Cesar Pascale \\ Palhares; ${ }^{5}$ Marcelo Henrique Otenio ${ }^{6}$
}

\section{Highlights}

Analisou-se a viabilidade econômica da implantação e utilização de um biodigestor tipo canadense.

Realizou-se a análise de cenários MOP: mais provável, otimista e pessimista.

A implantação do biodigestor apresentou viabilidade econômica em todos os cenários.

Valor presente líquido foi positivo e a taxa interna de retorno acima da taxa mínima de atratividade.

o payback simples e descontado e a relação benefício custo foram satisfatórias.

\begin{abstract}
This study aimed to analyze the economic viability of implementing and using a Canadian biodigester for power generation in a milk production system. Specifically, we intended to estimate the generated power production, the total production cost (TC), the total operating cost (TOC), and the effective operating cost (EOC) of $1 \mathrm{~kW}$ of power generated, and estimate the break-even point of the power produced. The research was carried out on a farm located in southern Minas Gerais (Brazil) from January to December 2017. Three scenarios were analyzed through the tree-point estimation (most likely, optimistic, and pessimistic). Scenario 1 considered the use of power for the acclimatization of free-stall barns during 13 hours day ${ }^{-1}$ plus the use of $50 \%$ of the produced biofertilizer. Scenario 2 considered the use of power during 13 hours day $^{-1}$ for the acclimatization of free-stall barns and milking parlor, which means an increase in power consumption estimated at $10 \%$ compared to scenario 1 , plus the use of $75 \%$ of the produced biofertilizer. Moreover,

1 Profa, Instituto Federal de Rondônia, IFRO, Ariquemes, RO. Bolsista Pró Doutoral Capes, Discente do Curso de Doutorado do Programa de Pós-Graduação em Ciências Veterinárias, UFLA, Lavras, MG, Brasil. E-mail: fabiana.alves@ifro.edu.br

2 Prof. Titular, Departamento de Medicina Veterinária, Universidade Federal de Lavras, UFLA, Lavras, MG, Brasil. E-mail: malopes@ufla.br

3 Prof., Universidade Federal do Acre, Rio Branco, AC, Brasil. E-mail: edumitke@gmail.com

4 Profs., Departamento de Administração e Economia, UFLA, Lavras, MG, Brasil. E-mail: andre.lima@ufla.br; francarv@ufla.br

5 Pesquisador, Empresa Brasileira de Pesquisa Agropecuária, EMBRAPA, São Carlos, SP, Brasil. E-mail: julio.palhares@ embrapa.br

${ }_{6}^{6}$ Pesquisador, EMBRAPA, Juiz de Fora, MG, Brasil. E-mail: marcelo.otenio@embrapa.br

* Author for correspondence
\end{abstract}

Received: Jun. 19, 2020 - Approved: Aug, 17, 2020 
scenario 3 considered the use of power for the acclimatization of free-stall barns during 6.5 hours day-1 plus $25 \%$ of the produced biofertilizer. All scenarios considered the amount charged per $\mathrm{kWh}$ by the Companhia Energética de Minas Gerais (CEMIG). Monte Carlo simulations were carried out with minimum acceptable rates of return ranging from zero to $50 \%$. Power generation was economically viable in all scenarios, with positive net present value (NPV), internal rates of return above the minimum acceptable rate of return, simple and discounted payback below the 10-year horizon, and satisfactory benefit-cost ratios. The EOC values of $1 \mathrm{kWh}$ of power were estimated at $R \$ 0.1990, R \$ 0.1791$, and $R \$ 0.3308$ for scenarios 1,2 , and 3 , respectively, whereas the mean total cost (TC) was $R \$ 0.5618( \pm 0.21)$ considering all scenarios, above the purchase values at CEMIG, which would be $R \$ 0.50$. The TC value was $R \$ 99,804.42$ for scenarios 1 and 2 , and $\mathrm{R} \$ 92,424.09$ for scenario 3 , with a minimum acceptable rate of return of 8.50 , while the TOC values were $\mathrm{R} \$ 69,486.62$ in scenarios 1 and 2 , and $\mathrm{R} \$ 62,229.66$ in scenario 3. The amount of power generated in all scenarios was higher than the break-even point. All Monte Carlo simulation models showed positive NPV values, indicating that there is a high probability of being above expectations.

Key words: Scenario analysis. Biofertilizer. Biogas. Profitability indicators. Waste treatment.

\section{Resumo}

Objetivou-se analisar a viabilidade econômica da implantação e utilização de um biodigestor tipo canadense para a geração de energia elétrica em um sistema de produção de leite. Especificamente, pretendeu-se estimar a produção de energia elétrica gerada, estimar o custo total de produção (CT), custo operacional total (COT) e custo operacional efetivo (COE) de um kW de energia gerada, e estimar o ponto de equilíbrio de energia produzida. A pesquisa foi realizada em uma propriedade localizada no sul de Minas Gerais, no período entre janeiro a dezembro de 2017. Realizou-se a análise de cenários MOP (mais provável, otimista e pessimista): cenários 1; 2 e 3. No cenário 1, foram considerados a utilização de energia elétrica para a climatização apenas dos galpões de free stall em $13 \mathrm{~h} \mathrm{dia}^{-1}$, mais aproveitamento de $50 \%$ do biofertilizante produzido. No cenário 2, a utilização da energia elétrica foi de $13 \mathrm{~h} \mathrm{dia}^{-1}$, utilizada para climatização dos galpões de free stall e sala de ordenha, um aumento de energia estimado em 10\%, em relação ao cenário 1, mais aproveitamento de $75 \%$ do biofertilizante produzido; e, no cenário 3, adotou-se a utilização de energia elétrica para a climatização dos galpões de free stall em $6,5 \mathrm{~h} \mathrm{dia}^{-1}$, mais aproveitamento de $25 \%$ do biofertilizante produzido. Em todos os cenários foi considerado o valor cobrado por kWh pela Companhia Energética de Minas Gerais (CEMIG). Realizou-se simulações de Monte Carlo com taxas mínimas de atratividade variando de zero a 50\%. A geração de energia elétrica apresentou viabilidade econômica em todos os cenários, apresentando valor presente líquido (VLP) positivos, taxas internas de retorno acima da taxa mínima de atratividade, payback simples e descontados abaixo do horizonte de 10 anos e relações benefício-custo satisfatórias. O COE de $1 \mathrm{kWh}$ de energia elétrica foi estimado em $R \$ 0,1990, R \$ 0,1791$ e $R \$ 0,3308$ para os cenários 1, 2 e 3, respectivamente, enquanto que o CT médio, considerando todos os cenários, foi de $\mathrm{R} \$$ $0,5618( \pm 0,21)$, acima dos valores de aquisição na CEMIG, que seria de $R \$ 0,50$. Os CT foram de $R \$ 99.804,42$ para os cenários 1 e 2, e de $\mathrm{R} \$ 92.424,09$ para o 3, com taxa mínima de atratividade de 8,50, enquanto que COT foi de $\mathrm{R} \$ 69.486,62$ nos cenários 1 e 2, e de $\mathrm{R} \$ 62.229,66$ no 3. Em todos os cenários, a quantidade de energia elétrica gerada foi superior ao ponto de equilíbrio. Todos os modelos de simulação de Monte Carlo apresentaram VPL positivos, indicando que há grande probabilidade de ficarem acima do esperado.

Palavras-chave: Análise de cenários. Biofertilizante. Biogás. Indicadores de rentabilidade. Tratamento de Dejetos. 


\section{Introduction}

Livestock sustainability has been a concern and object of several studies such as practice of design for deconstruction (DfD). This concept has the potential to limit construction environmental impacts by supporting disassembly and reuse of end-of-life building materials and reducing the use of concrete (Leso, Conti, Rossi, \& Barbari, 2018). It also aims to replace more expensive materials, but with lower thermal characteristics and higher environmental impact, with raw clay (unfired clay bricks) as building elements (Barbari, Monti, Rossi, Simonini, \& Guerri., 2014a,b). In this line, freshly-harvested rectangular bales of cereal straw have been increasingly used as a filling element for building walls (Conti et al., 2017), due to its high sustainability. Moreover, facilities have been designed based on the needs of outdoor animals and suitable building materials locally available (Rossi, Conti, Bambi, Monti, \& Barbari, 2018).

Power stands out among the essential items for milk production, as it is an important factor from planning to production management, going through all the processes until its preservation and purchasing by final consumers. Power expenditures have been identified by several authors (Lopes et al., 2015; Moraes et al., 2018; C. C. Santos; Almeida, \& Lopes, 2018) as an important component of milk production costs, with significant representativeness (mean of $7.16 \% \pm 0.86$ ) in the effective operating cost (EOC).

The growing increase in power consumption has been a concern, with an expected growth of $3.2 \%$ per year until 2050 , creating the need for investments in the sector. The agricultural sector has indicated a slight decrease in power consumption (0.4\%).
However, the sector continues to grow, but proportionally less than other sectors, such as the industry and transport sector, in the projection of the Ministry of Mines and Power (EBE - Empresa Brasileira Energética, [EBE 2014). Given the increased demand for power, there is a need for investments in the power sector, and the search for alternative sources is a necessity for the agricultural sector in Brazil to continue to grow and maintain the important economic and social role it occupies.

Due to the importance of the power generation sector, several researchers have assessed the economic viability of alternative sources. Among these initiatives are studies on the production of microalgae for power production (Holanda \& Ramos, 2011); use of biogas in pig farms (Lima \& Miranda, 2014; Martins \& Oliveira, 2011; Westrup et al., 2015); potential and economic/ environmental viability of biodigesters in a hospital environment (Nascimento, Maia, Silva, \& Santos, 2017); use of tidal power (Bispo et al., 2016); power production costs using biogas from manures of goat, cattle, and pig in semi-confinement systems (Calza, Lima, Nogueira, Siqueira, \& Santos, 2015); the economic viability of biogas from pig farming for power generation (Cervi, Esperancini, \& Bueno, 2010); biodigestion and biogas production using bovine manure (Dotto \& Wolff, 2012); anaerobic biodigestion economic analysis in beef cattle farming (Montoro, Santos, \& Lucas, 2013); and anaerobic biodigestion in pig farming (Rizzoni, Tobias, Bianchi, \& Garcia, 2012). However, only one study on the viability of generating power using biogas on dairy farming has been found (Coldebella, 2006).

Given the above, our study aimed to analyze the economic viability of implementing and using a Canadian biodigester for power 
generation in a milk production system in southern Minas Gerais, Brazil. Our main intentions were to estimate total generated power and costs (total cost [TC], total operating cost [TOC], and effective operating cost [EOC] per $1 \mathrm{kWh}$ of generated power), as well as the break-even point of power produced from biogas.

\section{Material and Methods}

The study was carried out from January to December 2017 on a farm located in southern Minas Gerais State, Brazil. The farm covers an area of 504 hectares, wherein coffee cultivation, pig farming, and dairy farming are developed. This study focused on dairy activity, which occupies an area of 100 ha.

The production system is intensive, housing all lactating and pre-calving cows in two free-stall barns with dimensions of $90 \times 30$ $\mathrm{m}$ (barn 1) and $60 \times 30 \mathrm{~m}$ (barn 2), and 230 and 198 free stalls, respectively, with a capacity to house about 428 purebred or grade Holstein cows. During the experiment, average daily total milk production was $11,864.95 \mathrm{~kg}( \pm 1,388.79$ $\mathrm{kg})$, with an average of $32.28 \mathrm{~kg}( \pm 2.68 \mathrm{~kg})$ milk per lactating cow. Feeding consisted of a complete diet with corn (Zea mays) silage and concentrate provided in a drive-through feed alley three times a day.

During the survey of information, two different stages were considered in this research (Lopes et al., 2019; Pelegrini et al., 2019). In the first stage, a full inventory of infrastructure and assets was carried out using a form and a field book to estimate depreciation and invested capital. Afterwards, the items were allocated into one of the following groups: improvement, equipment, and machinery.
Each improvement (pond for biofertilizer, pipe for waste, pipe for gas conduction, and shelter for electricity generator) was measured to produce a descriptive memorial summary. The value per square meter of construction was estimated as a function of the area, state of conservation, and finishing pattern. The current value was the product of the square meter value and the area of the improvement (Lopes et al., 2016). The equipment group consisted of two biodigester domes, two tanks before the biodigester, and a hydrogen sulfide filter. Whereas the machinery group consisted of an ER BR GMV 120 generator model 6.12T, a motor pump to drive the biofertilizer, and a solid separator machine.

In the second stage, the production system was visited, and the files were consulted for data collection regarding effective operating expenses, using field handbooks prepared for this purpose. The items of the effective operating cost per kWh of electricity produced were allocated into the following groups: labor, fixed taxes, maintenance and repair of machinery and improvements, and miscellaneous expenses. The item maintenance of infrastructure represented $4 \%$ of the asset values (Haack \& Oliveira, 2013), whereas values of 8.50 and $6.99 \%$ per year were adopted for the return on working capital, considering a value of $20 \%$ of EOC, as recommended by Lopes et al. (2016). These data were registered in a spreadsheet developed specifically for data electronic processing and economic viability analysis of the technology used for cattle effluent treatment. This spreadsheet included the two production cost structures (i.e., total production cost), which consisted of fixed and variable operating costs, both used by Lopes et al. (2019) and Pelegrini et al. (2019). The 
linear depreciation method was used in this study (Moraes et al., 2018).

The amount of power consumed in the milk production system (in kWh) was estimated considering the savings estimate informed by the company where the biodigester ${ }^{7}$ was installed. The power consumption was compared to those in similar milk production systems, but with no biodigester. The electricity tariff per kWh used in the study was that charged by Companhia Energética de Minas Gerais (CEMIG) to rural consumers from January to December 2017.

The amounts of nitrogen, phosphorus and potassium in the manure used in the crop were estimated at the Laboratory of Soils of the Federal University of Lavras. The information allowed estimating monetary values for the nutrients using the methods of Kiehl (1985) and Petzen et al. (2009), considering the grams of nutrient in commercial fertilizers. Thus, the kilogram value of nutrients was estimated per kilogram of manure. A similar procedure was adopted in two samples from the biofertilizer pond to estimate these nutrients in the biofertilizer, which were analyzed at the Laboratory of Water Analysis (LAADEG) of the UFLA, using only the method of Kiehl (1985).

A biogas equivalent of $0.0425 \mathrm{~m}^{3}(0.040$ to 0.045$)$ per kilogram of cow manure was considered to estimate daily biogas production (Oliver, Souza, Quadros, \& Valladares, 2008). The amounts of feces and urine excreted per animal was estimated considering the literature data, as a function of species (cattle), animal category, and the number of animals, just as proposed by I. A. dos Santos (2012b). Manure production per cow day ${ }^{-1}$ was obtained from the equation proposed by I. A. dos Santos (2012b), considering a manure production of $0.07 \mathrm{~kg} \mathrm{day}^{-1}$ per animal live kilogram. Annual biogas production was estimated using the method of Avaci et al. (2013).

Biofertilizer production was estimated considering its daily production and annual availability of the plant (Cervi, 2009). Revenues obtained from biofertilizer production were quantified by the method proposed by Cervi (2009), in which the amounts of nutrients are multiplied by the mean prices in the Lavras market during the first half of 2018.

EOC savings for biogas-derived power (in kWh), multiplied by the power rates charged by CEMIG from January to December 2017, were considered as cash flow revenue. The contents of nutrients in the dry matter were considered for manure and biofertilizer and multiplied by the prices of nutrients practiced in the market for commercial fertilizers.

Net present value (NPV), internal rate of return (IRR), and simple/ discounted payback were calculated as in Lopes, Junqueira, Brunh, Demeu and Silva (2017), and in Lopes et al. (2018). Whereas the benefit-cost ratio (BCR) was calculated as in Haraguchi, Siddiqi and Narayanamurti (2019). A 10-year horizon was adopted in estimating these indicators. Two discount rates were simulated: 1) $8.50 \%$ per year, as it is the financing rate available for rural producers who are willing to implement activities of such magnitude; and 2) $6.99 \%$ per year, as it is the savings interest rate accumulated in 2017 (Portal Brasil, 2017).

Three scenarios were analyzed through the tree-point estimation (most likely

${ }^{7}$ Information provided by the company Sansui on March 23, 2018 
[1], optimistic [2], and pessimistic [3]), as in Lage et al. (2016). In scenario 1, the produced power was used only to acclimatize freestall barns for 13 hours day ${ }^{-1}$, and only $50 \%$ of the biofertilizer produced was used. In scenario 2, the produced power was used for acclimatization of free-stall barns and milking parlor during 13 hours day ${ }^{-1}$, which means a $10 \%$ increase in power consumption (in $\mathrm{kWh}$ ) compared to scenario 1 , and $75 \%$ of the produced biofertilizer was used. Finally, in scenario 3, the produced power was used for acclimatization of free-stall barns during 6.5 -hour day ${ }^{-1}$, and only $25 \%$ of the produced biofertilizer was used. All scenarios considered the rates charged per kWh by CEMIG.

Two models for Monte Carlo simulation (Laponni, 2007) were also obtained using Microsoft Office Excel ${ }^{\circ}$. The following variables were used for constructing the models: units of electricity (in kWh) and biofertilizer (in L), the unit value paid per kWh of power, the unit cost of power (kWh) and of biofertilizer liter $\left(R \$ L^{-1}\right)$, fixed cost of the biodigester, investments of the biodigester, discount rate, and term. Each variable was determined from the collected data, considering the structure of the farm. Moreover, each of them was analyzed taking into account its characteristics within the production process of the farm.

The Monte Carlo simulation is a tool used in investment projects and has as premises the generation of random numbers correlated to cash inflows and outflows, which are the basis for NPV and IRR calculations. Random changes in cash flow function as random scenarios, which allows numerous possibilities for future outcomes (Torres, 2006). Given the minimum and maximum values, we used the spreadsheet and triangular function proposed by Laponni (2007), in which 1,000 possible values were generated for each variable, allowing data descriptive analysis. The Monte Carlo simulations were also carried out with minimum acceptable rates of return, which ranged from zero to $50 \%$.

The economic indices were compared through descriptive analyses using the MS Excel $^{\circledR}$ application. Then, they were grouped in tables to allow a better visual comparison, discussion, and presentation of results (Lopes et al., 2019).

\section{Results and Discussion}

Table 1 shows a summary of the resources required to implement a Canadian biodigester in a milk production system in southern Minas Gerais. These resources were useful for analysis and discussion of our results. The highest value was observed in the machinery group, which corresponded to $54.19 \%$ of the investments. The area for biodigester implementation must be considered despite having a low percentage (10.36\%) compared to the machinery group, as if it is not used for this purpose, it could be used for another productive activity. Amounts and percentages invested in biodigester implantation could not be compared with the few studies found in the literature (Lima \& Miranda, 2014; Nascimento et al., 2017; Westrup et al., 2015) since these did not detail the investment division. Moreover, most of the studies did not adopt a solid separator machine, which features a different production system with lower investments. In our study, such machine (Wamgrob K65) was acquired for $\mathrm{R} \$ 130,000.00$, which stands for $61.90 \%$ of the value spent on machinery and $33.54 \%$ of 
the value of the equity, but without considering the land. Martins and Oliveira (2011) estimated $19.23 \%$ of investments spent on machinery, a figure well below the one found here; however, these researchers mentioned no investment in a solid separator.

Table 1

Resources used for implementation of a Canadian biodigester for power generation from biogas in a milk production system in southern Minas Gerais (Brazil) in 2017 (in R\$ and US\$)

\begin{tabular}{|lccc|}
\hline Specification & Value (R\$) & Value (US\$) & (\%) \\
\hline Equity value with the land & $40,160.00$ & $12,395.06$ & 5.46 \\
\hline Equity value without the land & $34,7374.00$ & $10,7214 ., 20$ & 47.27 \\
\hline Improvement value & $13,2374.00$ & $40,856.17$ & 18.01 \\
\hline Equipment value & $5,000.00$ & $1,543.21$ & 0.68 \\
\hline Machinery value & $210,000.00$ & $64,814.81$ & 28.58 \\
\hline Total fixed assets & $734,908.00$ & $226,823.46$ & 100.00 \\
\hline Fixed assets per housed cow & 827.08 & 253.71 & 0.24
\end{tabular}

US\$ 1.00 equal to $\mathrm{R} \$ 3.26$, average price from 01/01/2017 to 12/31/2017 (Banco Central do Brasil [BCB], 2018).

The fixed asset housed cow $^{-1}$ of $\mathrm{R} \$ 827.08(0.24 \%$ of the infrastructure for biodigester recovery) represented only $3.99 \%$ of the $\mathrm{R} \$ 20,466.11$ (US\$ 6,277.95) referring to the fixed asset housed $\mathrm{cow}^{-1}$ of the production system, without considering the land. These figures are lower than the mean of $R \$ 18,516.0$ found by G. Santos and Lopes (2012a). However, it was $57.16 \%$ lower and hence more efficient if the IPCA inflation (Instituto Brasileiro de Geografia e Estatística [IBGE], 2018) accumulated in the period is considered.

The power generated by the Canadian biodigester represented 50.99, 53.62, and $34.22 \%$ of the power used in the production system for scenarios 1,2 , and 3, respectively.
The most likely scenario (scenario 1), in use on the farm during the data collection period, was promising because, in addition to helping in the environment preservation, which is one of the pillars of sustainability, also presented a positive NPV, IRR above the minimum acceptable rate of return, and simple and discounted payback shorter than the proposed horizon (Table 2). Moreover, there is already a plan to improve the use efficiency of available resources by increasing the use of biogas. This fact shows that an increase in cash flow revenues was due to better use of available biogas and biofertilizers to grow crops. If properlyused, biofertilizers can provide savings to production systems by decreasing spending on expensive commercial fertilizers. 


\section{Table 2}

Economic indicators for implementation and use of a Canadian biodigester for power generation from biogas in a free-stall milk production system in southern Minas Gerais (Brazil) in 2017, considering different discount rates

\begin{tabular}{|c|c|c|c|c|c|c|c|c|c|c|c|c|}
\hline \multirow{2}{*}{ Specification } & \multicolumn{4}{|c|}{ Scenario 1: most likely } & \multicolumn{4}{|c|}{ Scenario 2: optimistic } & \multicolumn{4}{|c|}{ Scenario 3: pessimistic } \\
\hline & \multicolumn{2}{|c|}{ TD 8.50\% } & \multicolumn{2}{|c|}{ TD 6.99\% } & \multicolumn{2}{|c|}{ TD $8.50 \%$} & \multicolumn{2}{|c|}{ TD $6.99 \%$} & \multicolumn{2}{|c|}{ TD 8.50\% } & \multicolumn{2}{|c|}{ TD 6.99\% } \\
\hline NPV (R\$) & \multicolumn{2}{|c|}{$833,998.47$} & \multicolumn{2}{|c|}{$923,956.09$} & \multicolumn{2}{|c|}{$1,229,614.23$} & \multicolumn{2}{|c|}{$1,387,529.26$} & \multicolumn{2}{|c|}{$184,626.64$} & \multicolumn{2}{|c|}{$227,961.72$} \\
\hline IRR (\%) & \multicolumn{2}{|c|}{43.31} & \multicolumn{2}{|c|}{43.30} & \multicolumn{2}{|c|}{59.15} & \multicolumn{2}{|c|}{59.15} & \multicolumn{2}{|c|}{17.48} & \multicolumn{2}{|c|}{17.48} \\
\hline Benefit-cost & \multicolumn{2}{|c|}{2.92} & \multicolumn{2}{|c|}{3.13} & \multicolumn{2}{|c|}{3.92} & \multicolumn{2}{|c|}{4.20} & \multicolumn{2}{|c|}{1.43} & \multicolumn{2}{|c|}{1.53} \\
\hline Payback & ${ }^{1 S}$ & ${ }^{2} \mathrm{D}$ & 1S & ${ }^{2} \mathrm{D}$ & 1S & ${ }^{2} \mathrm{D}$ & 1S & ${ }^{2} \mathrm{D}$ & 1S & ${ }^{2} \mathrm{D}$ & 1S & ${ }^{2} \mathrm{D}$ \\
\hline Years & 2 & 2 & 2 & 2 & 1 & 1 & 1 & 1 & 4 & 6 & 4 & 5 \\
\hline Months & 2 & 7 & 3 & 6 & 8 & 10 & 8 & 10 & 6 & 0 & 6 & 8 \\
\hline Days & 29 & 9 & 29 & 13 & 3 & 19 & 3 & 5 & 29 & 16 & 29 & 18 \\
\hline
\end{tabular}

${ }^{1} \mathrm{~S}=$ simple payback; ${ }^{2} \mathrm{D}=$ discounted payback.

Scenario 2 presented the best use of the available resources and the best cash flow revenue. It occurred because of an increase in production scale due to improved use of biogas. Moraes et al. (2018) observed that production scale influenced total operating production cost and hence profitability. The authors attributed such result to a physical structure optimization in the company since total operating cost per unit was reduced by increasing production scale up to certain levels. They also pointed out two alternatives for reducing total operating costs: increasing efficiency and production scale.

Scenario 3 has the disadvantage of using a small amount of the available resources, namely, only $25 \%$ of the biofertilizer and 6.5 hours of power generated from the biodigester, only for the free stall. These facts can compromise the feasibility of such infrastructure implementation. In the literature, Cervi et al. (2010) observed a lack of economic feasibility in implementing a biodigester for power generation in a pig farm, particularly because of a lack of suitable technical dimensioning of power demand for the generator group.

The implementation and use of a Canadian biodigester under the studied conditions showed economic viability in all scenarios (Table 2). NPV values were positive, therefore, the investor will have a financial gain (Chenço, 2016). IRR was above the minimum acceptable rates of return; thus, the investment will have a higher financial return. Moreover, the simple and discounted paybacks were below the proposed horizon (Table 3), thereby, all the invested capital will be recovered before the 10-year horizon. The benefit-cost ratios were also satisfactory, with values of 2.92, 3.92, and 1.43 for scenarios 1,2 , and 3 , respectively, for interest rates of $8.50 \%$, and $3.13,4.20$, and 1.53 for scenarios 1,2 , and 3 , respectively, for an interest rate of $6.99 \%$. These figures indicate that the project costs are lower relative to the provided benefits. In short, our 
results show that, in practical terms, there will be asset development, and the investor has, in this activity, a good investment option, i.e., there will be wealth creation.

In the present study, we do not consider savings from replacing water with biodigester effluent for the cleaning of freestall barns, which, depending on water intake system (gravity or with power use), could be a way to reduce washing costs. The reuse of water and effluents in rural properties should be encouraged due to a forthcoming need to save and conserve the available water resources. These alternatives may contribute to dairy farming economic and environmental feasibility, as water is expected to be an increasingly scarce resource for all sectors of society. 


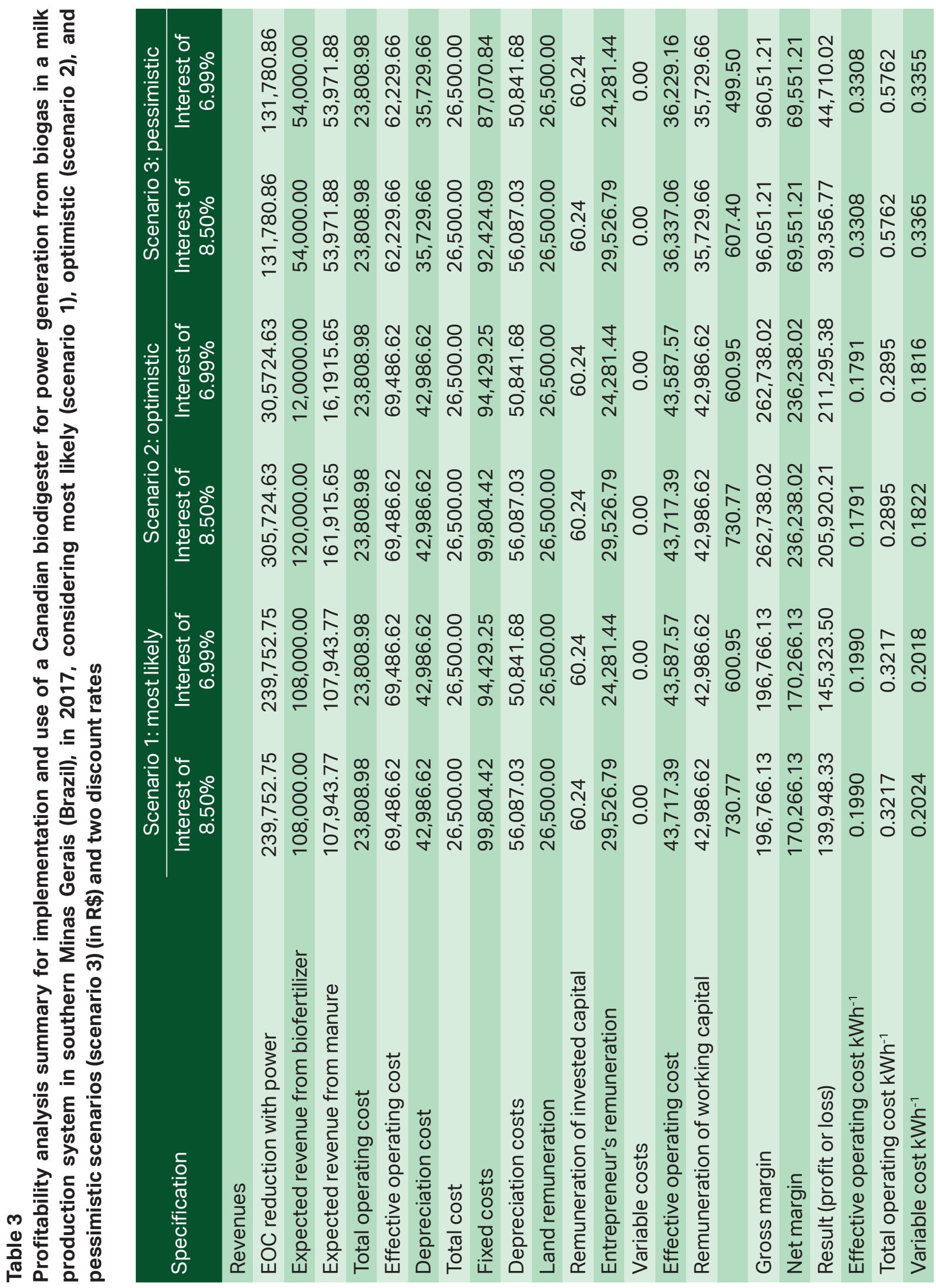




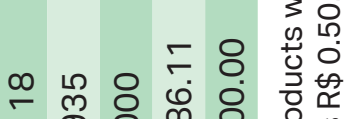

స

० 0 0

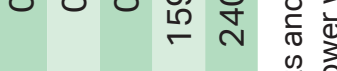

ஸे

ก้

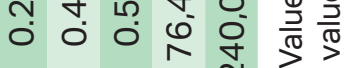

$\therefore$ 辛

क

+

กิ

กั

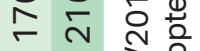

ก

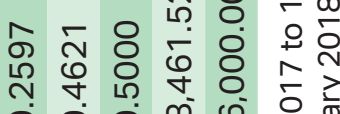

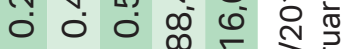

$\sim \bar{\sim}$ 迹

응

$\mp+\frac{1}{4}$

(ั)

त 흥

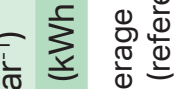

这

$\therefore$ का

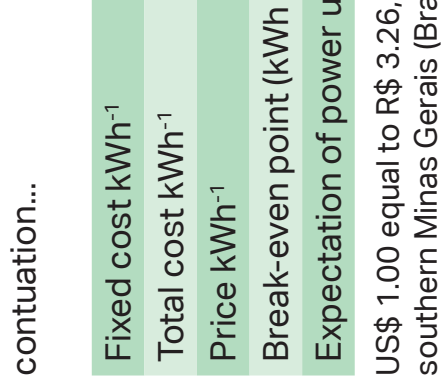


It is important to highlight that agricultural production systems need investments to mitigate environmental impacts; however, if these are not reconciled with a reduction in costs, they can make productive activity unfeasible. Therefore, production systems and respective costs must be understood to use all their productive potential, maximize profits, and identify bottlenecks to be corrected, thus ensuring economic and environmental sustainability, once the environmental impacts caused by the developed activities can be reduced.

Coldebella, Souza, Ferri and Kolling (2008) found that the economic feasibility of generating power from biogas depends on power generator daily operation. Studies of this nature can direct the investments of producers, leading to an excellent result if the project is well dimensioned.

Klavon, Lansing, Mulbry, Moss and Felton (2013) studied different types of biodigesters in 16 dairy farms in the United States, with herds of up to 250 cows, and found that only six of them showed economic viability to use a biodigester for power generation, considering a 20-year horizon and an interest rate of $8 \%$ per year. The authors also reported that studies show that, in the United States, biodigesters were economically viable only on farms with more than 500 cows. However, no studies have assessed real cost data for properties with fewer animals. The farm evaluated in our study had on average 411 and 435 cows in 2016 and 2017, respectively, which may have justified the economic viability of all scenarios. As each region has its peculiarity, further studies are needed to indicate whether such an investment would be viable or not.

Table 3 shows a summary of the profitability analysis of the Canadian biodigester in all the proposed scenarios. Total revenues were expected in $\mathrm{R} \$ 293,752.75, \mathrm{R} \$$ $305,724.63$, and $\mathrm{R} \$ 131,780.86$ for scenarios 1 , 2, and 3, respectively. These values correspond to the sum of expected revenue from electricity generation $(45.05,39.25$, and $40.97 \%)$, from biofertilizer $(45.02,52.96$, and $40.96 \%)$, and from manure $(9.93,7.79$, and $18.07 \%$ ), in scenarios 1,2 , and 3 , respectively. These figures were lower than those obtained by Cervi (2009), whose percentage of revenue obtained with biofertilizer (62.53\%) was higher than the percentage of revenue from power (37.43\%) in a case study in a unit of pig production. However, Cervi (2009) disregarded the expectation of revenue from the use of manure, and it is one of the few studies that consider biofertilizer as an item to generate revenue on a farm. Most studies have not considered such a possibility of revenue. In practice, producers who have plantations on their farms use the product for fertilization, which improves soil fertility (Silva et al., 2010) and reduces spending on chemical fertilizers. Moreover, biofertilizer use reduces costs with crop fertilization, although it means a reduction in revenue at first (Lopes, Gomide, Franco, \& Santos., 2011).

The expected power consumption was 216,000.00, 240,000.00, and 108,000.00 kWh year $^{-1}$ for scenarios 1,2 , and 3, respectively. The optimistic scenario (scenario 2 ) provided savings of up to $\mathrm{R} \$ 120,000.00$ year $^{-1}$, considering a power rate of $\mathrm{R} \$ 0.50 \mathrm{kWh}^{-}$ 1 charged by the local power distribution company. Coldebella et al. (2008) found that a biodigester power-generation system is feasible even under less than ideal operating conditions since the highest estimated value was $\mathrm{R} \$ 239.83 \mathrm{MWh}$, whereas that of the power distribution company was $\mathrm{R} \$ 300.00 \mathrm{MWh}$. 
The pessimistic scenario (scenario 3) had low power use (20\%) and showed a total cost (TC) per kWh of power ( $\mathrm{R} \$ 0.8558$ and $\mathrm{R} \$$ 0.8062) (Table 3) above the amount charged by the power distribution company ( $\mathrm{R} \$ 0.50)$. However, it did not make the investment unfeasible, as the revenues from manure and biodigester contributed to a positive result when added to the revenue from power generation. Therefore, the use of the Canadian biodigester for power generation showed to economically feasible under the study conditions, considering 411 and 435 cows in 2016 and 2017, respectively, which are in line with the national reality. In this sense, economic viability studies should be carried out in farms with other production profiles and under different situations and locations within the national territory, so that conditions under which such a technology would be viable can be specified.

The TCs per kWh of power in scenarios 1 and 2 (Table 3) were lower than the rates charged by the power distribution company. These TCs could be more attractive for all scenarios if all potential use of available resources were analyzed. The optimistic scenario had the best use of the resources, with an estimate of $50 \%$ of power and $75 \%$ of biofertilizer. The result (profit or loss) was positive in all analyzed scenarios, showing that the activity has conditions to persist in the long term.

In all scenarios, the break-even point could be estimated. The highest was observed in the pessimistic scenario (scenario 3), with a value of $342,944.02 \mathrm{kWh}$ year $^{-1}$ at an interest of $8.50 \%$. Nevertheless, it was well below the estimated production potential $(509,890.00$ $\mathrm{kWh}$ year $^{-1}$ ) of about 1.13 times the amount estimated in scenario 3.

All indicators and Monte Carlo simulations (MCS) showed that investing in a Canadian biodigester for power generation from biogas seems to be a good deal. Table 4 shows the descriptive statistics of the net present value for MCS1 and MCS2. This analysis contains important information about the results of events that the manager may encounter during the operating cycle.

Table 4

Statistical summary of net present value (NPV) for implementation and use of a Canadian biodigester for power generation from biogas in a free-stall milk production system in southern Minas Gerais (Brazil), in 2017, considering Monte Carlo simulations 1 (MCS1) and 2 (MCS2)

\begin{tabular}{lcc|}
\hline Statistical data & NPV MCS1 & NPV MCS2 \\
\hline Minimum (R\$) & $36,202.66$ & $24,268.19$ \\
\hline Maximum (R\$) & $892,498.73$ & $904,034.34$ \\
\hline Expected value (R\$) & $510,273.99$ & $466,217.02$ \\
\hline Median (R\$) & $512,631.21$ & $463,967.26$ \\
\hline Standard deviation (R\$) & $157,169.22$ & $158,638.16$ \\
\hline CV (\%) & 30.80 & 34.03 \\
\hline Probability of NPV > 0 (\%) & 100.00 & 100.00 \\
\hline
\end{tabular}


The minimum and maximum NPV values ( $R$ \$ 24,268.19 and $R \$$ 904,034.34, respectively) were observed in MCS2, which justified its higher coefficient of variation compared to MCS1. The risks involving the amount of power generated were considered in MCS1 and MCS2, with the minimum, intermediate, and maximum values of 54,000 , 216,000, and $240.00 \mathrm{kWh}^{-1}$, respectively. These values were adopted for being the most likely to occur on the farm at the time of the study. The maximum value would be estimated for a possible expansion of the system, which is already foreseen by the producer, while the minimum would be the lowest value to be reached in case of failures in the process of using biogas. Similar criteria were adopted to define the minimum $(4,680,696.64 \quad \mathrm{~L})$, most likely $(9,361,393.27 \mathrm{~L})$, and maximum $(14,042,089.91 \mathrm{~L})$ values of biofertilizer in the simulations. The MCS1 also considered unit costs of electricity of $\mathrm{R} \$ 0.1946, \mathrm{R} \$ 0.2162$, and $\mathrm{R} \$ 0.358 \mathrm{KWh}^{-1}$ for minimum, most likely, and maximum values, respectively. Yet, for MCS2, the unit cost of power was $\mathrm{R} \$ 0.2162$ $\mathrm{KWh}^{-1}$. The variables biodigester fixed cost $(\mathrm{R} \$$ 15,977.00), initial investment ( $R \$ 388,746.80)$, discount rate (9\%), project horizon (10 years), and biofertilizer price ( $\left.\mathrm{R} \$ 0.0115 \mathrm{KWh}^{-1}\right)$ were fixed for both MSC1 and MCS2.

The statistical summary indicated NPV values with medians of $\mathrm{R} \$ 512,631.21$ and $\mathrm{R} \$ 463,967.26$, and coefficients of variation of 30.80 and $34.03 \%$ for MCS1 and MCS2, respectively. All analyzed scenarios had positive NPV values, indicating a high probability of being above expectations. Therefore, investment is advisable, but the manager must be aware of the power market prices and farm consumption profile. Power consumption of electricity-dependent machines and equipment could, for example, be checked and, if needed, one should consider replacing them with others that consume less energy to improve efficiency on the farm.

Table 5 shows the probability of NPV > zero in Monte Carlo simulations for a minimum acceptable rate of return (MARR), ranging from zeroto $50 \%$ for MCS1 and MCS2. Inboth, a MARR value equal to zero indicates the probability of $100 \%$ success in the enterprise, which remains very close to a MARR of $20 \%$. However, MARR values between 40 and $50 \%$ are less promising, indicating higher investment risks. When bank loans are available, and considering the studied situations, interest rates above $20 \%$ per year require greater attention and caution by the investor before making a decision. Enterprises dealing with waste treatment and environment conservation can receive funding from the BNDES (Portuguese acronym for National Bank for Economic and Social Development), with an interest rate of $8.50 \%$ per year, which has a great chance of being successful considering our findings (Portal Brasil, 2017). 


\section{Table 5}

Summary of Monte Carlo simulations of net present value (NPV) for minimum acceptable rates of return (MARR) ranging from zero to $50 \%$ of the implementation and use of a Canadian biodigester for power generation from biogas in a free-stall milk production system in southern Minas Gerais (Brazil), in 2017, considering Monte Carlo simulations 1 (MCS1) and 2 (MCS2)

\begin{tabular}{lcc}
\hline MARR (\%) & Probability of NPV > 0 MCS1 (\%) & Probability of NPV > 0 MCS2 (\%) \\
\hline 0 & 100.00 & 100.00 \\
10 & 99.90 & 99.80 \\
20 & 97.10 & 94.80 \\
\hline 30 & 70.40 & 61.90 \\
40 & 18.20 & 14.00 \\
50 & 1.00 & 0.50 \\
\hline
\end{tabular}

\section{Conclusions}

The implementation and use of a Canadian biodigester in a free-stall milk production system in southern Minas Gerais (Brazil) was economically viable and had positive NPV, IRR above the analyzed minimum acceptable rates of return, simple and discounted paybacks below the proposed horizon, and satisfactory benefit-cost ratios (above 1).

The effective operating costs for 1 kWh of power were estimated at $\mathrm{R} \$ 0.1990, \mathrm{R} \$$ 0.1791 , and $\mathrm{R} \$ 0.3308$ for scenarios 1,2 , and 3 , respectively. Whereas the mean total cost was $\mathrm{R} \$ 0.5618( \pm 0.21)$ for all scenarios, which is above the acquisition values at CEMIG (R\$ 0.50).

The total costs were $\mathrm{R} \$ 99,804.42$ and $\mathrm{R} \$ 92,424.09$ for scenarios 1 and 2 , respectively, with a minimum acceptable rate of return of 8.50 . Whereas the total operating cost was $R \$ 69,486.62$ in scenarios 1 and 2 and $R \$ 62,229.66$ in scenario 3.

In all scenarios, the amount of power generated was higher than the break-even point, i.e., about five times the amount considered in scenario 3 .

All Monte Carlo simulation models showed positive net present values.

\section{Acknowledgments}

The authors would like to thank the FEDERAL INSTITUTE OF SCIENCE AND TECHNOLOGY OF RONDÔNIA (IFRO) for the financial support in translating this paper, CAPES for granting of a scholarship to the first author, and Fazenda Catete, on behalf of Mr Gustavo Portugal, for making available the property data for the study.

\section{References}

Avaci, A. B., Souza, S. N. M. de, Chaves, L. I., Nogueira, C. E. C., Niedzialkoski, R. K., \& Secco, D. (2013). Economic evaluation of microgeneration of electricity from biogas of swine manure. Revista Brasileira de Engenharia Agrícola e Ambiental, 17(4), 456-462. doi: 10.1590/S141543662013000400015 
Banco Central do Brasil (2018). Dólar americano. Recuperado de http://www4. bcb.gov.br/pec/taxas/port/ ptaxnpesq. asp?id=txcotacao

Barbari, M., Monti, M., Rossi, G., Simonini, S., \& Guerri, F. S. (2014a). Proposal for a simple method of structural calculation for ordinary earthen buildings in rural areas. Journal of Food, Agriculture \& Environment, 12(2), 897-903. Recuperado de https://www.researchgate.net/ publication/ 275291723__ Proposal_ for_a_simple_method_of_structural_ calculation_for_ordinary_earthen_ buildings_in_rural_areas

Barbari, M., Monti, M., Rossi, G., Simonini, S., \& Guerri, F. S. (2014b). Simple methods and tools to determine the mechanical strength of adobe in rural areas. Journal of Food, Agriculture \& Environment, 12(2), 904-909. Recuperado de https://www.researchgate. net/publication/275292515_Simple_ methods _and_tools_to_determine_the mechanical_strength_of_adobe_in_rural_ areas

Bispo, A. D. R., Bonfim, J. M. S., Pereira, J. R. de S., Jr., Machado, L. C., Gama, M. M. O., \& Almeida, T. A. de. (2016). Estudo da exploração, geração de eletricidade, impactos ambientais e viabilidade econômica de projetos da energia de maremotriz. Ciências Exatas e Tecnológicas, 3(2), 75-86. Recuperado de https://periodicos.set.edu.br/index.php/ cadernoexatas/article/view/2808/1701

Empresa de Pesquisa Energética (2014). Demanda de Energia 2050. Brasília, DF.

Calza, L. F., Lima, C. B., Nogueira, C. E. C., Siqueira, J. A. C., \& Santos, R, F. (2015). Avaliação dos custos de implantação de biodigestores e da energia produzida pelo biogás. Engenharia Agrícola, 35(6), 990-
997. doi: 10.1590/1809-4430-Eng.Agric. v35n6p990-997/2015

Cervi, R. G. (2009). Avaliação econômica do aproveitamento do biogás e biofertilizante produzido por biodigestão anaeróbia: estudo de caso em unidade biointegrada. Dissertação de mestrado, Universidade Estadual Paulista, Botucatu, SP, Brasil. Recuperado de https://repositorio.unesp.br/ bitstream/ handle/11449/90632/cervi_rg_me_ botfca.pdf?sequence=1\&isAllowed=y

Cervi, R. G., Esperancini, M. S. T., \& Bueno, O. D. C. (2010). Viabilidade econômica da utilização do biogás produzido em granja suinícola para geração de energia elétrica. Engenharia Agrícola, 30(5), 831-844. doi: 10.1590/S0100-69162010000500006

Chenço, E. C. (2016). Fundamentos em finanças. Curitiba: IESDE Brasil AS.

Coldebella, A. (2006). Viabilidade do uso do biogas da bovinoculturas e suinocultura para geração de energia elétrica e irrigação em propriedades rurais. Dissertação de mestrado, Universidade Estadual do Oeste do Paraná, Cascavel, PR, Brasil.

Coldebella, A., Souza, S. N. M. de, Ferri, P., \& Kolling, E. M. (2008). Viabilidade da geração de energia elétrica através de um motor gerador utilizando biogás da suinocultura. Informe Gepec, 12(2), 44-55. Recuperado de http://e-revista.unioeste.br/index.php/ gepec/article/view/2186/1698

Conti, L., Goli, G., Monti, M., Pellegrini, P., Rossi, G., \& Barbari, M. (2017). Simplified method for the characterization of Rectangular Straw Bales (RSB) thermal conductivity. In IOP Conference Series: Materials Science and Engineering, Prague, Czech Republic, Czech Republic. (vol. 245). doi: 10. $1088 / 1757-899 X / 245 / 5 / 052035$ 
Dotto, R. B., \& Wolff, D. B. (2012). Biodigestão e produção de biogás utilizando dejetos bovinos. Ciências Naturais e Tecnológicas, 13(1), 13-26. Recuperado de https://periodicos.ufn.edu.br/index. php/disciplinarumNT/article/viewFile/ $1291 / 1223$

Haack, S. C., \& Oliveira, G. G. de. (2013). Análise de viabilidade econômica e financeira de projetos sustentáveis no setor energético: estudo de caso para implantação de biodigestores no semiárido baiano. Revista Econômica do Nordeste, 44(Supl.), 363-382. Recuperado de https://ren. emnuvens.com.br/ren/ article/view/36/18

Haraguchi, M., Siddiqi, A., \& Narayanamurti, V. (2019). Stochastic cost-benefit analysis of urban waste-to-energy systems. Journal of Cleaner Production, 224(3), 751-765. doi: 10.1016/j.jclepro.2019.03.099

Holanda, L. R., \& Ramos, F. de S. (2011). Análise da viabilidade econômica da energia elétrica gerada através das microalgas. Revista Eletrônica Sistemas \& Gestão, 6(3), 327-346. doi: 10.7177/sg.2011.v6. n3.a7

Instituto Brasileiro de Geografia e Estatística (2018). Indicadores IBGE: sistema nacional de índices de preços ao consumidor. Recuperado de http:// ftp.ibge.gov.br/Precos_Indices de_Precos_ao__Consumidor/IPCA/ Fasciculo_Indicadores_IBGE/ipcainpc_201807caderno.pdf

Kiehl, E. J. (1985). Fertilizantes orgânicos. Piracicaba: Agronômica Ceres.

Klavon, K. H., Lansing, S. A., Mulbry, W., Moss, A. R., \& Felton, G. (2013). Economic analysis of small-scale agricultural digesters in the United States. Biomass and Bioenergy, 54, 36-45. doi: 10.1016/j. biombioe.2013.03.009
Lage, L. A., Lopes, M. A., Lopes, F. C. F., Gama, M. A. S., Ribeiro, C. G. S., Rogríguez, N. M., \& Demeu, F. A. (2016). Economic feasibility of adding sunflower oil to elephant grass-based diets of lactating dairy cows. Semina: Ciências Agrárias, 37(4), 2313-2320, (Supl. 1). doi: 10.5433/16790359.2016v37 n4Supl1p2313

Laponni, J. (2007). Projetos de investimento na empresa. Rio de Janeiro: Elsevier Brasil.

Leso, L., Conti, L., Rossi, G., \& Barbari, M. (2018). Criteria of design for deconstruction applied to dairy cows housing: a case study in Italy. Agronomy Research, 16, 794-805. doi: 10.15159/AR.18.085

Lima, D. F. S., \& Miranda, G. J. (2014). Análise da viabilidade econômico financeira do aproveitamento do biogás para produção de energia elétrica. Custos e @gronegócio, 10(3), 83-99. Recuperado de https://www.researchgate.net/ publication/273831043_Analise_da_ viabilidade_economico_financeira do_aproveitamento_do_biogas_para_ producao_de_energia_eletrica

Lopes, M. A., Gomide, D. R., Franco, A. F., Neto, \& Santos, G. dos. (2011). Resultados econômicos de um sistema de produção de leite na região de Varginha - Sul de Minas Gerais. Boletim de Indústria Animal, 68(1), 7-15. Recuperado de http://www. iz.sp.gov.br/bia/index.php/bia/article/ view/1062

Lopes, M. A., Junqueira, L. V., Bruhn, F. R. P., Demeu, A. A., \& Silva, M. das D. (2017). Technical efficiency and economic viability of different cattle identification methods allowed by the Brazilian traceability system. Semina: Ciências Agrárias, 38(1), 467480. doi: 10.5433/1679-0359.2017v38n1 p467 
Lopes, M. A., Moraes, F. de, Bruhn, F. R. P., Carvalho, F. de M., Lima, A. L. R., Reis, B. E. M., \& Viafara, J. A. S. (2019). Análisis de la rentabilidad de la actividad lechera de propriedades participantes del programa "Balde Cheio". Revista de Medicina Veterinaria, 38(1), 15-27. doi: 10.19052/ mv.vol1.iss38.2

Lopes, M. A., Moraes, F. de, Carvalho, F., Peres, A., Bruhn, F., \& Reis, E. (2015). The effect of technological levels on profits of milk production systems participating in the "full bucket" program: a multicase study. Semina: Ciências Agrárias, 36(4), 2909-2922. doi: 10.5433/16790359.2015v36n4 p2909

Lopes, M. A., Reis, E. M. B., Demeu, F. A., Mesquita, A. A., Rocha, A. G. F., Pelegrini, D. F.,... Teixeira, F. E. P., Jr. (2016). Uso de ferramentas de gestão na atividade leiteira: um estudo de caso no sul de Minas Gerais. Revista Científica de Produção Animal, 18(1), 26-44. doi: 10.25066/ agrotec.v39i1.34302

Lopes, M. A., Vieira, J. A., Lima, F. H. S. de, Demeu, F. A., Bruhn, F. R. P., Pereira, A.,... Casas, P. S. (2018). Technical and economic efficiency of bovine weighing methods. Semina: Ciências Agrárias, 39(3), 1167-1180. doi: 10.5433/1679-0359.2018v39n3p1167

Martins, F. M., \& Oliveira, P. A. V. de. (2011). Análise econômica da geração de energia elétrica a partir do biogás na suinocultura. Engenharia Agrícola, 31(3), 477-486. doi: 10.1590/S0100-69162011000300008

Montoro, S. B., Santos, D. F. L., \& Lucas, J., Jr. (2013). Análise econômica de investimentos que visam à produção de biogás e biofertilizante por meio de biodigestão anaeróbia na bovinocultura de corte. RAuNp, 5(2), 23-34. Recuperado de http://www.spell.org.br/documentos/ ver/10400/analise-economica-deinvestimentos-que-visam-a-producaode-biogas-e-biofertilizante-por-meio-deiodigestao-anaerobia-na-bovinoculturade-corte/i/pt-br

Moraes, F., Lopes, M. A., Carvalho, F. M., Peres, A. A. C., Bruhn, F. R. P., Lima, A. L. R., \& Cardoso, M.G. (2018). Effect of the scale of production on the cost-effectiveness of milk production systems belonging to the "Balde Cheio" program. Semina: Ciências Agrárias, 39(3), 1211-1224. doi: 10.5433/ 1679-0359.2018v39n3p1211

Nascimento, K. L. S. do, Maia, S. M. F., Silva, S. J. C. da, \& Santos, E. L. (2017). Geração de energia elétrica e viabilidade técnicoeconômica de um biodigestor no setor hospitalar. Pubvet, 11(12), 1263-1273. doi: 10.22256/pubvet.v11n12.1263-1273

Oliver, A. P. M., Souza, A. A., Neto, Quadros, D. G., \& Valladares, R. E. (2008). Manual de treinamento em biodigestão. Salvador: Instituto Winrock, Brasil.

Pelegrini, D. P., Lopes, M. A., Demeu, F. A., Rocha, A. G. F., Bruhn, F. R. P., \& Casas, O. S. (2019). Effect of socioeconomic factors on the yields of family-operated milk production systems. Semina: Ciências Agrárias, 40(3), 1199-1214. doi: 10.5433/1679-0359.2019v40n3p1199

Petzen, J., Wolfanger, C., Bonhotal, J., Schwarz, M., Terry, T., \& Youngers, N. (2009). Eagleview compost dairy barn. Warsaw: NY Farm Viability Institute.

Portal Brasil (2017). Caderneta de poupança: índices mensais: rendimentos creditados no dia $1^{\circ}$ de cada mês. Brasília, DF. Recuperado de http://www.portalbrasil. net/poupanca_mensal.htm 
Rizzoni, L. B., Tobias, A. C. T., Bianchi, M. D., \& Garcia, J. A. D. (2012). Biodigestão anaeróbia no tratamento de dejetos de suínos. Revista Científica Eletrônica de Medicina Veterinária, 9(18), 1-20. Recuperado de http://faef.revista.inf.br/ imagens_arquivos/arquivos_destaque/ W34ebZOEZuzvEvG_ 2013-6-28-18-1237.pdf

Rossi, G., Conti, L., Bambi, G., Monti, M., \& Barbari, M. (2018). Poultry farming solutions for a sustainable development of marshlands areas of South Iraq. Agronomy Research, 16(2), 574-581. doi: 10.15159/ AR.18.058

Santos, C. C., Almeida, G. A. de, Jr., \& Lopes, M. A. (2018). Dairy activity in family farming in Minas Gerais, Brazil: production costs and cost-effectiveness analysis. Semina: Ciências Agrárias, 39(3), 1255-1266. doi: 10.5433/1679-0359.2018v39n3p1255

Santos, G., \& Lopes, M. A. (2012a). Indicadores de rentabilidade do centro de custo produção de leite em sistemas intensivos de produção. Boletim de Indústria Animal, 69(1), 1-11. Recuperado de http://www. iz.sp.gov.br/bia/index.php/bia/article/ view/1042
Santos, I. A. dos. (2012b). Emissões de Gases de Efeito Estufa (GEE) associadas à bovinocultura: o valor fertilizante do esterco e o impacto da biodigestão anaeróbia. Dissertação de mestrado, Universidade Federal de Itajubá, Itajubá, MG, Brasil. Recuperado de https://repositorio.unifei.edu.br/xmlui/ bitstream/handle/123456789/1204/ dissertacao_santos1_2012.pdf? sequence $=3$ \&isAllowed $=y$

Silva, J. C. P. M. da, Motta, A. C. V., Pauletti, V., Veloso, C. M., Favaretto, N., Barcellos, M.,... Silva, L. F. C. (2010). Esterco de gado leiteiro associado à adubação mineral e sua influência na fertilidade de um latossolo sob plantio dreto. Revista Brasileira de Ciencia do Solo, 34(2) 453-463. doi: 10.1590/S0100-06832010000200019

Torres, O. F. (2006). Fundamentos da engenharia econômica e da análise de projetos. São Paulo: Thomson Learning.

Westrup, G., Duarte, G. W., Alberton, J., Niehues, R. C., Rocha, D. A., \& Vandresen, S. (2015). Estudo da viabilidade econômica de geração de energia elétrica a partir de biogás proveniente de dejetos de suínos de uma propriedade rural em Forquilhinha/ SC. Revista Ciência \& Cidadania, 1(1), 19-37. Recuperado de http://periodicos. unibave.net/index.php/cienciaecidadania/ article/view/18 
